\title{
Pengungkapan Marah di Jejaring Sosial
}

\author{
Safinatunnajah \& Ilmi Amalia \\ Fakultas Psikologi UIN Syarif Hidayatullah Jakarta \\ safinafina97@gmail.com, ilmi.amalia@uinjkt.ac.id
}

\begin{abstract}
The aim of this study was to determine the effect of the big five personality, social support, collectivismindividualism, and anonymity on expressing anger on social networking sites (SNS). This research used quantitative with multiple regression analysis methods. The samples in this study were 210 respondents who posted anger content on social networking sites, aged at least more than 18 years old. Obtained by nonprobability sampling technique. In this study, researcher adapted and collected the data with four questionnaires; the anger-out scale is from STAXI measuring instrument, Big Five Inventory (BFI), Interpersonal Support Evaluation List, and collectivism-individualism. To test the validity of the instrument, researcher was using Confirmatory Factor Analysis (CFA). The results showed there was a significant difference from the type of big five, social, collectivism-individualism and anonymity to expressing anger on social networking sites by 18.6.
\end{abstract}

Keywords: Anger-out, big five personality, social support, collectivism-individualism, anonymity, social networking sites

\begin{abstract}
Abstrak
Tujuan dari penelitian ini adalah untuk mengetahui pengaruh tipe kepribadian big five, dukungan sosial, kolektivisme-individualisme, dan anonimitas terhadap pengungkapan marah di jejaring sosial. Penelitian ini menggunakan pendekatan kuantitatif dengan metode analisis regresi berganda. Sampel pada penelitian ini berjumlah 210 responden pengunggah perasaan marah di jejaring sosial yang berusia 18 tahun keatas. Diperoleh dengan teknik non-probability sampling. Dalam penelitian ini peneliti mengadaptasi dan memodifikasi instrumen pengumpulan data yaitu skala anger-out dalam alat ukur STAXI, Big Five Inventory (BFI), Interpersonal Support Evaluation List, dan kolektivisme-individualisme. Uji validitas instrument dilakukan dengan menggunakan Confirmatory Factor Analysis (CFA). Hasil penelitian menunjukkan bahwa terdapat pengaruh yang signifikan dari tipe kepribadian big five, dukungan sosial, kolektivismeindividualisme, dan anonimitas terhadap pengungkapan marah di jejaring sosial yakni sebesar 18,6.
\end{abstract}

Kata kunci: Pengungkapan marah, tipe kepribadian big five, dukungan sosial, kolektivisme-individualisme, anonimitas, jejaring sosial

\section{Pendahuluan}

Segala kehidupan manusia saat ini bisa dilakukan di rumah hanya dengan mengakses internet. Oleh sebab itu, internet menjadi kebutuhan utama untuk menunjang kehidupan sehari-hari masyarakat saat ini. Berdasarkan hasil survei perilaku penggunaan internet yang dilakukan oleh APJII (2018), dari 171,17 juta jiwa pengguna internet, 18,9\% menggunakannya untuk bermedia sosial. Media sosial merupakan sebuah media yang dimanfaatkan sebagai sarana untuk bersosialisasi yang dilakukan secara daring sehingga memungkinkan individu untuk bisa saling berinteraksi tanpa dibatasi ruang dan waktu (Rustian, 2012). 
Para penggunanya bisa dengan mudah berpartisipasi, berbagi, dan menciptakan isi meliputi blog, jejaring sosial, wiki, forum dan dunia virtual (Tosepu, 2018). Media sosial dapat dikelompokkan ke dalam beberapa kategori, salah satunya yaitu jejaring sosial. Jejaring sosial lebih mengacu pada situs atau website yang digunakan sebagai tempat berkumpulnya banyak orang tanpa pembatas dan memiliki jalur ikatan seperti keluarga, teman, rekan bisnis dan lain sebagainya. Situs jejaring sosial meliputi Facebook, Youtube, Twitter, Instagram, LinkedIn, Myspace dan sejenisnya. Berbeda dengan akun laman pesan seperti email, Whatsapp, dan lain sebagainya yang lebih tertutup ruang lingkupnya. Beberapa fitur yang disediakan di jejaring sosial antara lain, seperti mengunggah dan mengomentari foto, video dan status, memposting acara dan berbagai kegiatan sehari-hari. Setiap media sosial memiliki fitur uniknya tersendiri (Yu \& John-baptiste, 2016).

Pengungkapan emosi di jejaring sosial menjadi suatu hal yang umum terjadi bagi setiap pengguna. Tidak hanya keadaan yang menyenangkan tetapi juga kekesalan atau emosi negatif yang dialami, menjadi suatu hal yang umum bagi setiap pengguna untuk mengutarakannya di media sosial. Berdasarkan penelitian yang dilakukan oleh Lee (2012) dari semua reaksi emosi, kemarahan adalah salah satu emosi yang paling umum diungkapkan di jejaring sosial. Selain itu juga Fan, Zhao, Chen, dan Xu (2014) menemukan bahwa kemarahan lebih cepat menyebar di jejaring sosial daripada jenis emosi lain, seperti kegembiraan, rasa jijik atau kesedihan. Dengan kata lain, berdasarkan penelitiannya kemarahan lebih mungkin untuk di-retweet atau disukai, tidak hanya oleh relasi yang dekat dengan individu tetapi juga yang jauh. Oleh karena itu, emosi marah lebih cepat viral, daripada emosi lain.

Seperti pada kasus Florence Sihombing pada tahun 2014, seorang mahasiswa UGM yang mengunggah status di jejaring sosial Path, berisi makian kepada warga Jogja. Florence menghimbau warga kota lain seperti Jakarta untuk tidak berkunjung ke kota tersebut. Hal tersebut terjadi lantaran Flo merasa kesal akibat ditolak ketika membeli bahan bakar sepeda motornya, karena ia dianggap melanggar antrian. Status tersebut kemudian menjadi viral di berbagai jejaring sosial seperti Twitter dan Facebook, hingga menimbulkan kemarahan publik dan menghantarkan hingga ke ranah hukum. Akibat unggahan kemarahannya di jejaring sosial itu, ia dikenai hukuman dua bulan penjara (Sucahyo, 2015).

Menurut Martin \& Vieaux (2016), yang membuat kemarahan di jejaring sosial begitu bermasalah adalah mengenai bagaimana cara individu menanggapi perasaan marah mereka. Individu yang biasanya mengungkapkan kemarahannya di jejaring sosial, akan sering mengungkapkannya dengan cara menyinggung orang lain atau bahkan hingga merusak hubungan. Begitu pula, orang-orang yang mengoceh secara daring, akan sering mengalami masalah dengan kemarahan mereka secara luring pula (Martin, Coyier, VanSistine, \& Schroeder, 2013).

Alasan mengapa banyak orang memposting tentang kemarahan yang mereka alami, karena banyak orang percaya bahwa melepaskan amarah dengan tindakan fisik atau menulis adalah mekanisme coping yang sehat, meskipun beragam penelitian menyatakan sebaliknya (Bushman, Baumeister, \& Phillips, 2001). Berdasarkan penelitiannya, Bushman, (2002) menunjukkan bahwa mengungkapkan marah di jejaring sosial diibaratkan seperti halnya menggunakan bensin untuk memadamkan api, karena hal itu menyebabkan orang-orang lebih memikirkan tentang kemarahan yang mereka alami daripada terus maju (move on) untuk berusaha menyelesaikannya atau menjalani hal yang lain. Demikian pula, sebuah penelitian menunjukkan bahwa kemarahan sebenarnya akan meningkat ketika orang-orang memperkuat luapan kemarahan individu, dan menurun ketika individu berusaha untuk memahami situasi marah mereka (Parlamis, 2012).

Selain sebagai bentuk dari katarsis, seperti penelitian tentang situs pengungkapan marah daring yang dilakukan oleh Martin et al. (2013). Alasan mengapa individu senang mengungkapkan kemarahan di jejaring sosial, karena individu merasakan efek lebih tenang dan lega setelah dapat meluapkan amarahnya. Kedua, merasa dihargai dengan memperoleh komentar dari orang lain, dan juga, seseorang merasa tidak sendirian dalam menghadapi amarah yang ada dalam diri. Namun 
selain dampak jangka pendek yang ditimbulkan, berdasarkan hasil penelitian yang dilakukan Martin et al. (2013) bahwa pengungkapan marah secara daring yang dilakukan secara terus menerus dapat membuat individu menjadi seseorang yang lebih pemarah dan dapat memiliki kecenderungan untuk mengekspresikan kemarahan dengan cara yang lebih maladaptif.

Selain itu pengungkapan marah di jejaring sosial yang dilakukan secara intens juga dapat memicu penularan keadaan emosi kepada yang membacanya. Kramer, Guillory, dan Hancock (2014) menyatakan bahwa penularan emosi dapat terjadi tanpa melalui interaksi secara langsung dan tanpa informasi non-verbal. Hal ini diungkapkan Kramer, Guillory, dan Hancock (2014) berdasarkan perolehan hasil penelitian yang ditemukannya bahwa, ketika pengguna jejaring sosial banyak melihat konten yang bersifat negatif maka akan memiliki kemungkinan yang lebih besar untuk memposting konten yang bersifat negatif pula. Banyak pula penelitian yang menunjukkan bahwa komentar yang diunggah oleh individu di lingkungan daring memiliki pengaruh besar terhadap sikap dan pendapat pembaca (Lee \& Jang, 2010; Walther, DeAndrea, Kim, \& Anthony, 2010; dalam Rösner \& Krämer, 2016). Menurut Rosner dan Kramer (2016), komentar daring memengaruhi pendapat dan sikap orang lain yang melihat, selain itu juga memengaruhi perilaku untuk memposting komentar sama seperti komentar kebanyakan.

Berdasarkan hasil penelitian yang telah dipaparkan sebelumnya, bahwa pengungkapan perasaan marah dapat memberikan dampak negatif yang begitu besar tidak hanya kepada individu yang mengunggahnya tetapi juga orang lain yang membacanya. Bagi pengunggah kemarahan hal ini akan membuatnya semakin bertambah marah atau bahkan menyesal dikemudian hari, dan bagi pembaca akan ikut merasa marah atau tersulut emosi.

Berdasarkan hasil penelitian yang dilakukan oleh Mill, Kööts-Ausmees, Allik, dan Realo (2018) menemukan bahwa sifat-sifat kepribadian memiliki pengaruh secara langsung pada kemarahan dalam kehidupan sehari-hari dengan profil yang berbeda untuk efek pada anger in dan anger out. Pada penelitian lain yang dilakukan oleh Yu dan John-Baptiste (2016) menunjukkan bahwa dukungan sosial di dunia nyata juga memengaruhi seseorang untuk tidak mengungkapkan emosi mereka di jejaring sosial, dan individu merasa lebih baik ketika setelah berbicara dengan seorang teman daripada dengan mempostingnya di jejaring sosial mengenai emosi yang sedang mereka alami. Hal lain yang paling banyak diteliti terkait pengungkapan emosi seseorang di dunia maya yakni dipengaruhi oleh unsur anonimitas. Christopherson (2007) berpendapat bahwa anonimitas memengaruhi cara orang berkomunikasi secara daring, karena seseorang dapat menyerang orang lain, dan menimbulkan bahaya tanpa menghadapi targetnya secara langsung.

Selain itu, seperti yang dikemukakan oleh Rosner (2016) bagaimana komentar daring memengaruhi pendapat dan sikap orang lain untuk memposting komentar yang sama seperti komentar kebanyakan. Hal ini menggugah peneliti untuk mengaitkan unsur budaya yakni nilai kolektivisme dan individualisme sebagai variabel independen yang memicu pengungkapan marah di jejaring sosial. Peneliti berpendapat kemungkinan individu berani mengungkapkan amarah di jejaring sosial secara terang-terangan dengan menyindir orang lain atau situasi tertentu dipengaruhi oleh budaya individualis. Sebaliknya, nilai budaya kolektivis muncul ketika banyak individu berani menyerang orang lain di jejaring sosial saat banyak orang melakukan hal yang sama.

Berdasarkan penjelasan tersebut, maka tujuan dari penelitian ini adalah untuk mengetahui pengaruh tipe kepribadian big five, dukungan sosial, kolektivisme-individualisme, dan anonimitas terhadap pengungkapan marah di jejaring sosial. 


\section{Kajian Teori}

\section{A. Pengungkapan marah di jejaring sosial}

\section{Definisi}

Menurut Spielberger (1995) marah adalah suatu keadaan yang memiliki beragam intensitas dari yang ringan hingga yang berat, biasanya akan disertai dengan perubahan psikologis juga keadaan biologis dari sistem saraf otonom. Marah merupakan suatu keadaan yang bersifat sosial sehingga biasanya terjadi jika mendapat perlakuan tidak adil atau tidak menyenangkan di dalam interaksi sosial. Meskipun permusuhan umumnya melibatkan perasaan marah yang intens, konsep ini juga memiliki hubungan dengan seperangkat sikap dan perilaku yang kompleks yakni menjadi jahat, kejam, pendendam, dan sering sinis.

Kemarahan di internet adalah kemarahan yang diungkapkan secara daring melalui berbagai macam tempat yang berbeda (misalnya Facebook, Twitter, forum diskusi, email) ditunjukkan dengan perilaku agresif secara daring melalui ejekan, menyebar rumor, membuat laman marah atau bahkan meretas ke akun orang lain untuk berkomentar yang tidak pantas. Individu yang biasanya mengungkapkan kemarahannya secara daring akan sering mengungkapkannya dengan cara menyinggung orang lain atau dapat merusak hubungan (Martin dan Vieaux, 2016).

Berdasarkan beberapa definisi yang telah dikemukakan sebelumnya, peneliti memadukan definisi kemarahan yang dikemukakan oleh Spielberger et al. (1995) dan Martin dan Vieaux (2016) bahwa pengungkapan marah di jejaring sosial adalah suatu respon alamiah dengan intensitas yang beragam, terjadi akibat adanya perlakuan tidak adil atau tidak menyenangkan yang diungkapkan secara daring melalui akun jejaring sosial, ditunjukkan dengan perilaku agresif melalui ejekan, menyebarkan rumor, membuat laman marah atau bahkan meretas ke akun orang lain untuk membuat komentar yang tidak pantas.

\section{Aspek pengungkapan marah}

Spielberger (1995) mengatakan bahwa cara mengekspresikan kemarahan tiap individu berbedabeda. Hal tersebut dapat dibedakan menjadi tiga macam, yaitu anger in, anger out, dan anger control.

\section{Anger in}

Pengungkapan emosi marah yang dirasakan oleh individu, cenderung ditekankan ke dalam dirinya tanpa mengekspresikannya ke luar. Misalnya, ketika sedang marah seseorang lebih memilih diam dan tidak mau menceritakannya pada siapa pun atau tidak menegur orang yang membuatnya mejadi marah.

\section{Anger out}

Merupakan reaksi ke luar atau obyek yang dimunculkan oleh individu ketika dalam keadaan marah atau reaksi yang dapat diamati secara umum. Kondisi seperti ini bisa menjadi perbuatan merusak, misalnya memukul atau menendang sesuatu yang ada didekatnya, namun setelah itu dia akan merasakan kelegaan karena perasaan marah yang dirasakan sudah terpuaskan. Anger out berkaitan dengan ketidakmampuan individu mengekspresikan emosinya secara konstrukif dan asertif.

\section{Anger control}

Kemampuan individu untuk bisa mengontrol atau melihat sisi positif dari permasalahan yang dihadapi dan berusaha konsisten menjaga sikap yang positif walau menghadapi situasi yang buruk. Misalnya, mencari solusi yang baik atau tepat ketika menghadapi suatu persoalan agar tidak merugikan diri sendiri maupun orang lain. 
Dalam hal ini, dikarenakan peneliti hanya mencari individu yang mengekspresikan marahnya dengan cara memunculkan reaksi kepermukaan sehingga dapat diamati khususnya di jejaring sosial. Maka, peneliti hanya menggunakan teori anger out sebagai aspek pengungkapan marah dalam penelitian ini.

\section{B. Tipe Kepribadian Big Five}

\section{Definisi}

Kepribadian big five menurut (McCrae \& Costa, 1999) adalah suatu pendekatan yang digunakan dalam psikologi untuk melihat kepribadian manusia melalui pengelompokkan kata-kata atau bahasa yang digunakan di dalam kehidupan sehari-hari untuk menggambarkan ciri-ciri individu yang membedakan dengan individu lain yang tersusun ke dalam lima buah dimensi kepribadian yang telah dibentuk menggunakan analisis faktor. Lima dimensi tipe kepribadian big five antara lain; Neuroticism (N), Extraversion (E), Openness (O), Agreableness (A), dan Conscientiousness (C). Tipe kepribadian ini dirancang untuk menangkap ciri-ciri kepribadian yang orang anggap paling penting dalam diri individu. Kata big dimaksudkan untuk merujuk pada temuan bahwa masingmasing faktor menggolongkan sejumlah besar sifat yang lebih spesifik.

\section{Dimensi}

Dimensi tipe kepribadian big five menurut McCrae dan Costa (1999) sebagai berikut:

\section{Agreeableness $(A)$}

Individu pada tipe kepribadian A memiliki karakter seperti mudah percaya, murah hati, pengalah, mudah menerima, dan memliki perilaku yang baik. Dan sebaliknya, individu yang memiliki skor rendah, individu cenderung memiliki karakter penuh kecurigaan, pelit, tidak ramah, mudah marah, dan penuh kritik terhadap orang lain.

\section{Conscientiousness $(C)$}

Individu pada tipe kepribadian C dideskripsikan sebagai individu yang teratur, terkontrol, terorganisasi, ambisius, terfokus pada pencapaian, dan memiliki disiplin diri. Secara umum, tipe kepribadian $\mathrm{C}$ biasanya pekerja keras, berhati-hati, tepat waktu, dan mampu bertahan. Sebaliknya, jika individu memiliki skor $C$ yang rendah cenderung tidak teratur, ceroboh, pemalas, serta tidak memiliki tujuan dan lebih mungkin menyerah saat mulai menemui kesulitan dalam mengerjakan sestuatu.

\section{Neuroticism $(N)$}

Individu yang memiliki skor tinggi pada $\mathrm{N}$ cenderung penuh dengan kecemasan, tempramental, mengasihani diri sendiri, sangat sadar akan dirinya sendiri, emosional, dan rentan terhadap gangguan yang berhubungan dengan stres. Sedangkan, individu dengan skor N yang rendah biasanya tenang, tidak tempramental, puas dengan dirinya sendiri, dan tidak emosional.

\section{Extraversion $(E)$}

Individu dengan tipe kepribadian E yang memiliki skor tinggi memiliki kecenderungan penuh kasih sayang, ceria, senang berbicara, senang berkumpul, dan menyenangkan. Sebaliknya, individu yang memiliki skor rendah pada tipe kepribadian ini cenderung untuk tertutup, pendiam, penyendiri, pasif, dan tidak mempunyai cukup kemampuan untuk mengekspresikan emosi yang kuat.

\section{Openness to Experience $(O)$}

Individu dengan tipe kepribadian $\mathrm{O}$ yang memiliki skor tinggi secara konsisten mencari pengalaman yang berbeda dan bervariasi. Individu ini biasanya kreatif, imajinatif, penuh dengan rasa penasaran, terbuka pada ide yang berbeda, emosi yang berbeda, nilai, pengalaman yang berbeda, serta lebih 
suka dengan hal yang bervariasi.Sedangkan, individu dengan skor yang rendah akan cenderung untuk bertahan pada hal-hal yang tidak asing, yang mereka tahu akan seperti apa hasilnya dan memiliki sifat yang konservasional, rendah hati, konservatif, dan memiliki rasa ingin tahu yang terendah.

\section{Dukungan Sosial}

\section{Definisi}

Menurut Cohen dan Hoberman (1983) dukungan sosial mengacu pada berbagai sumber daya yang disediakan oleh ikatan interpersonal seseorang, dimana terkait dengan persepsi ketersediaan empat fungsi dukungan yang berbeda.

\section{Dimensi}

Cohen, dan Hoberman (1983) menyimpulkan empat bentuk dukungan sosial yang merupakan persepsi ketersediaan dukungan sosial pada diri individu:

1. Dukungan praktis (tangible support) atau bantuan-bantuan yang bersifat pelayanan seperti membantu dalam melakukan kegiatan sehari-hari maupun bantuan secara finansial. Keluarga merupakan sebuah sumber pertolongan praktis dan konkrit diantaranya: bantuan langsung dari orang yang diandalkan seperti materi, tenaga dan sarana. Manfaat dukungan ini adalah mendukung pulihnya energi atau stamina dan semangat yang menurun selain itu individu merasa bahwa masih ada perhatian atau kepedulian dari lingkungan terhadap seseorang yang sedang mengalami kesusahan atau penderitaan.

2. Dukungan informasi (appraisal support) atau suatu bentuk bantuan yang membantu individu dalam memahami kejadian yang menekan dengan lebih baik serta memberikan pilihan strategi coping yang harus dilakukan guna menghadapi kejadian tersebut. Keluarga berfungsi sebagai kolektor dan diseminator informasi tentang dunia yang dapat digunakan untuk mengungkapkan suatu masalah. Manfaat dari dukungan ini adalah dapat menekan munculnya suatu stresor karena informasi yang diberikan dapat menyumbangkan aksi sugesti yang khusus pada individu. Aspekaspek dalam dukungan ini adalah nasihat, usulan, saran, petunjuk dan pemberian informasi.

3. Dukungan harga diri (self esteem) atau suatu bentuk bantuan dimana individu merasakan adanya perasaan positif akan dirinya bila dibandingkan keadaan yang dimiliki dengan orang lain, yang membuat individu merasa sejajar dengan orang lain seusianya. Keluarga bertindak sebagai sebuah bimbingan umpan balik, membimbing dan menengahi masalah serta sebagai sumber validator identitas anggota keluarga, diantaranya: memberikan support, pengakuan, penghargaan dan perhatian.

4. Dukungan belonging, suatu bentuk bantuan dimana individu tahu bahwa ada orang lain yang dapat diandalkan ketika ia ingin melakukan suatu kegiatan bersama dengan orang lain. Keluarga sebagai sebuah tempat yang aman dan damai untuk istirahat dan pemulihan serta membantu penguasaan terhadap emosi. Manfaat dari dukungan ini adalah secara emosional menjamin nilainilai individu (baik pria maupun wanita) akan selalu terjaga kerahasiaannya dari keingintahuan orang lain. Aspek-aspek dari dukungan emosional meliputi dukungan yang diwujudkan dalam bentuk afeksi, adanya kepercayaan, perhatian dan mendengarkan serta didengarkan. 


\section{Budaya Kolektivisme-Individualisme}

\section{Definisi dan dimensi kolektivisme-individualisme}

Menurut Gelfand dan Triandis (1998) budaya adalah bentuk dari pola sikap bersama, kepercayaan, kategorisasi, definisi-diri, norma, definisi peran, dan nilai-nilai yang diorganisasikan di sekitar hal yang dapat diidentifikasi di antara mereka yang berbicara bahasa tertentu, selama periode sejarah tertentu, dan dalam wilayah geografis yang dapat ditentukan.

Menurut Gelfand dan Triandis (1998) dalam memahami budaya pada konteks psikologi sosial menganalisanya hanya dalam hal individualisme dan kolektivisme. Adapun penjelasan dari masing-masing dimensi adalah sebagai berikut:

\section{Kolektivisme}

Kolektivisme pada individu ditandai dengan adanya kerjasama yang bagus dalam kelompok, namun akan menjadi orang yang sangat berbeda di luar kelompoknya. Individu dengan budaya kolektivis menempatkan dirinya sebagai suatu bagian dari kelompok. Dalam mencapai tujuan, individu memprioritaskan tujuan yang menjadi kesepakatan kelompok.

\section{Individualisme}

Individualisme pada individu ditandai dengan adanya kecakapan dalam berhubungan dengan orang luar, membentuk kelompok baru, dan mudah bergaul dengan orang baru. Selain itu orang dengan budaya individualis juga lebih mementingkan hal-hal yang terkait dengan dirinya sendiri.

\section{E. Anonimitas}

\section{Definisi}

Menurut Christopherson (2007) anonimitas secara tradisional dipahami sebagai ketidakmampuan orang lain untuk mengidentifikasi seseorang atau bagi orang lain untuk mengidentifikasi diri sendiri. Namun, sebenarnya ada dua kategori anonimitas yang luas: anonimitas teknis dan anonimitas sosial. Anonimitas teknis mengacu pada penghapusan semua informasi identitas yang bermakna tentang orang lain dalam pertukaran materi. Ini dapat mencakup penghapusan nama seseorang atau informasi pengidentifikasi lainnya dari komunikasi Internet. Anonimitas sosial mengacu pada persepsi orang lain dan/atau diri seseorang sebagai hal yang tidak dapat diidentifikasi karena kurangnya petunjuk yang digunakan untuk menghubungkan identitas dengan individu tersebut. Dengan kata lain, mungkin bukan karena seseorang benar-benar anonim dalam konteks sosial, tetapi individu menganggap dirinya anonim bagi orang lain.

Lapidot-lefler dan Barak (2012) mendefinisikan anonimitas sebagai suatu hal yang berfokus pada dimensi yang tidak dapat diidentifikasi, yang cakupannya luas dan lebih kearah pribadi daripada sekedar hanya tanpa nama. Faktor yang tidak dapat diidentifikasi mengacu pada kondisi realistis, karena tidak diketahui oleh teman daring dalam hal mengidentifikasi detail pribadi, seperti; jenis kelamin, berat badan, usia, pekerjaan, asal etnis, alamat tempat tinggal dan sebagainya.

Sehingga dapat disimpulkan bahwa anonimitas adalah suatu keadaan dimana individu merahasiakan serta tidak dapat diidentifikasi identitas yang sebenarnya oleh orang lain meliputi nama, jenis kelamin, suku, ras, pekerjaan, tempat tinggal juga ciri penampilan ketika berada di ruang daring. 


\section{Metode}

Populasi dalam penelitian ini merupakan individu (1) berusia di atas 18 tahun yang menggunakan setidaknya salah satu jejaring sosial twitter, facebook atau instagram. Alasan pemilihan populasi ini bahwa, individu sudah masuk pada tahap dewasa awal. Sehingga individu dapat mengisi kuesioner tanpa perlu mendapat persetujuan dari pihak ketiga (orangtua atau wali), serta responden pada usia tersebut diasumsikan lebih memahami dalam proses pengisian kuesioner. Selain berdasarkan usia, kriteria berikutnya ditentukan berdasarkan (2) pernah atau aktif mengungkapkan marah di jejaring sosial yang dimiliki. Sampel dalam penelitian ini berjumlah 210 responden. Teknik pengumpulan sampel yang penulis gunakan dalam penelitian ini yaitu menggunakan teknik nonprobability sampling.

Dalam penelitian ini, peneliti menyebarkan kuesioner penelitian secara daring menggunakan google form. Alasan menggunakan google form dalam penelitian ini yang pertama karena penelitian ini merupakan isu yang sensitif sehingga, diharapkan responden akan tetap merasa nyaman saat mengisi kuesioner. Kedua memperoleh sampel yang lebih luas dengan biaya yang rendah. Ketiga, menghemat penggunaan kertas. Keempat, menghindari resiko responden melewatkan beberapa item saat mengisi survey (Iqbal, Rosramadhana, Amal, \& Rumapea, 2018).

\section{Hasil}

\section{Tabel 1}

\section{Gambaran Umum Subjek Penelitian}

\begin{tabular}{ll}
\hline Variabel & $\mathbf{n}(\%)$ \\
\hline Jenis Kelamin & $186(88.6)$ \\
Perempuan & $24(11.4)$ \\
Laki-laki & \\
Usia & $78(37.14)$ \\
$18-21$ & $129(61.42)$ \\
$22-40$ & $3(1.4)$ \\
$41-47$ & \\
Suku & $123(58.6)$ \\
Jawa & $28(13.3)$ \\
Sunda & $15(7.1)$ \\
Betawi & $1(0.5)$ \\
Rongkong & $1(0.5)$ \\
Mongondow & $1(0.5)$ \\
Makassar & $3(1.4)$ \\
Bugis & $2(1)$ \\
Minahasa & $5(2.4)$ \\
Minang & $1(0.5)$ \\
Kerinci & $4(1.9)$ \\
Lampung & $2(1)$ \\
Melayu & $7(3.3)$ \\
Batak &
\end{tabular}




\begin{tabular}{|c|c|}
\hline Variabel & n (\%) \\
\hline Sampit & $1(0.5)$ \\
\hline Dayak & $3(1.4)$ \\
\hline Sasak & $1(0.5)$ \\
\hline Tionghoa & $7(3.3)$ \\
\hline Bali & $4(1.9)$ \\
\hline Maluku & $1(0.5)$ \\
\hline \multicolumn{2}{|l|}{ Domisili } \\
\hline Jakarta & $33(15.7)$ \\
\hline Banten & $36(17.1)$ \\
\hline Jawa Barat & $41(19.5)$ \\
\hline Jawa Tengah & $34(16.2)$ \\
\hline Jawa Timur & $29(13.8)$ \\
\hline Sulawesi & $4(1.9)$ \\
\hline Sumatera & $14(6.7)$ \\
\hline Kalimantan & $10(4.8)$ \\
\hline Bali & $6(2.9)$ \\
\hline Aceh & $1(0.5)$ \\
\hline Luar negeri & $2(1)$ \\
\hline $\begin{array}{l}\text { Aplikasi untuk mengungkapkan } \\
\text { marah }\end{array}$ & \\
\hline Twitter & $93(44.3)$ \\
\hline Instagram & $56(26.7)$ \\
\hline Facebook & $13(6.2)$ \\
\hline $\begin{array}{l}\text { Lainnya (whastapp story, whisper \& } \\
\text { blog) }\end{array}$ & $48(22.8)$ \\
\hline \multicolumn{2}{|l|}{ Identitas di jejaring sosial } \\
\hline Tidak Anonim & $174(82.9)$ \\
\hline Anonim & 35 (16.7) \\
\hline
\end{tabular}

Berdasarkan data pada tabel 1 dapat diketahui bahwa mayoritas subjek penelitian berjenis kelamin perempuan, yaitu sebesar $88.6 \%$ atau berjumlah 186 orang. Pada kategori usia untuk mempermudah perhitungan, peneliti mengkategorikan usia responden ke dalam tiga kategori berdasarkan rentang usia perkembangan, yaitu remaja akhir 18 - 21 tahun, dewasa awal $22-40$ tahun dan dewasa akhir 41 tahun ke atas. Mayoritas responden pada penelitian ini berusia 22 hingga 40 tahun, yaitu sebanyak 129 orang $(61.42 \%)$.

Mayoritas responden pada penelitian ini bersuku jawa, sejumlah 123 orang dengan persentase 58.6\%. Lalu mayoritas berdomisili di provinsi Jawa barat tersebar dari daerah Depok, Bogor, Bandung, dll yaitu sebanyak 41 orang dengan persentase $19.5 \%$. Aplikasi yang digunakan sebagian besar responden (44.3\%) untuk mengungkapkan marah adalah jejaring sosial twitter. Gambaran demografi yang terakhir yakni responden dalam mengungkapkan marah di jejaring sosialnya, mayoritas tetap menggunakan akun dengan identitas asli (tidak anonim) yaitu $82.9 \%$ atau 
sejumlah 174 orang. Sedangkan responden yang menggunakan identitas lain (anonim) hanya berjumlah 35 orang atau $16.7 \%$.

\section{Hasil Analisis Deskriptif}

\section{Tabel 2}

\section{Hasil Deskriptif Statistik Variabel Penelitian}

\begin{tabular}{|c|c|c|c|c|c|}
\hline \multicolumn{6}{|l|}{ Deskriptif Statistik } \\
\hline & $\mathrm{N}$ & Minimum & Maksimum & Mean & Std. Deviasi \\
\hline Anger Out & 210 & 35 & 75 & 49.78 & 8.473 \\
\hline Neuroticism & 210 & 24 & 71 & 49.97 & 9.183 \\
\hline Extraversion & 210 & 25 & 73 & 50.00 & 9.018 \\
\hline Openness to experience & 210 & 24 & 71 & 50.24 & 8.720 \\
\hline Agreeableness & 210 & 28 & 68 & 50.00 & 7.474 \\
\hline Conscientiousness & 210 & 28 & 74 & 50.03 & 9.004 \\
\hline Tangible support & 210 & 24 & 71 & 50.11 & 8.475 \\
\hline Appraisal support & 210 & 28 & 68 & 49.89 & 8.844 \\
\hline Self-esteem & 210 & 27 & 68 & 50.09 & 8.794 \\
\hline Belonging & 210 & 29 & 69 & 49.99 & 8.734 \\
\hline Kolektivisme & 210 & 26 & 75 & 49.99 & 8.818 \\
\hline Individualisme & 210 & 24 & 68 & 50.09 & 9.506 \\
\hline Valid N (listwise) & 210 & & & & \\
\hline
\end{tabular}

Sebagaimana yang tertera pada tabel 2 diketahui bahwa kolom $\mathrm{N}$ menjelaskan mengenai jumlah sampel pada setiap variabel, yaitu berjumlah 210. Kemudian dalam kolom minimum dan maximum menjelaskan nilai terendah dan tertinggi pada setiap variabel. Pada variabel anger out (pengungkapan marah) dengan skor terendah 35 dan skor tertinggi 75. Skor terendah untuk variabel neuroticism yaitu 24 dan skor tertinggi 71. Pada variabel extraversion skor terendah 25 dan skor tertinggi 73. Untuk variabel openness to experience skor terendah 24 dan skor tertinggi 71 . Variabel agreeableness skor terendah sejumlah 28 dan skor tertinggi 68. Pada variabel conscientiousness skor terendah sejumlah 28 dan skor tertinggi 74.

Pada variabel tangible skor terendah 24 dan skor tertinggi 71. Untuk variabel appraisal skor terendah 28 dan skor tertinggi 68. Variabel self-esteem memiliki skor terendah 27 dan skor tertinggi 68. Sedangkan pada variabel belonging skor terendah sejumlah 29 dan skor tertinggi 69. Pada variabel kolektivisme-individualisme, dimensi kolektivisme, skor terendah sejumlah 26 dan skor tertinggi 75. Sedangkan pada variabel individualisme skor terendah 24 dan skor tertinggi 68. 
Kategorisasi Subjek Variabel Penelitian

Tabel 3

Kategorisasi Skor Variabel Penelitian

\begin{tabular}{lllll}
\hline Variabel & Frekuensi & & Persentase & \\
& Rendah & Tinggi & Rendah & Tinggi \\
\hline Anger Out & 114 & 96 & $54.3 \%$ & $45.7 \%$ \\
Neuroticism & 98 & 112 & $46.7 \%$ & $53.3 \%$ \\
Extraversion & 110 & 100 & $52.4 \%$ & $47.6 \%$ \\
Openness to experience & 107 & 103 & $51 \%$ & $49 \%$ \\
Agreeableness & 101 & 109 & $48.1 \%$ & $51.9 \%$ \\
Conscientiousness & 105 & 105 & $50 \%$ & $50 \%$ \\
Tangible & 102 & 108 & $48.6 \%$ & $51.4 \%$ \\
Appraisal & 106 & 104 & $50.5 \%$ & $49.5 \%$ \\
Self-esteem & 98 & 112 & $46.7 \%$ & $53.3 \%$ \\
Belonging & 107 & 103 & $51 \%$ & $49 \%$ \\
Kolektivisme & 93 & 117 & $44.3 \%$ & $55.7 \%$ \\
Individualisme & 71 & 139 & $33.8 \%$ & $66.2 \%$ \\
\hline
\end{tabular}

Sebagaimana disebutkan dalam tabel 3 variabel anger-out (pengungkapan marah di jejaring sosial) hasil sebaran paling banyak pada kategori rendah 54.3\%. Pada variabel neuroticism 53.3\% didominasi pada kategori tinggi. Variabel extraversion 52.4\% lebih banyak pada kategori rendah, begitu pula pada variabel openness to experience terdapat $51 \%$ lebih banyak respon pada kategori rendah. Variabel agreeableness respon lebih besar pada kategori tinggi 51.9\%. Pada variabel conscientiousness jumlah respon dengan kategori rendah dan tinggi setara 50\%.

Pada variabel tangible sejumlah responden mendominasi dengan frekuensi skor kategori tinggi sebanyak 51.4\%. Pada variabel appraisal perbandingan pada kategori rendah lebih besar $50.5 \%$ dari kategori tinggi, sedangkan pada variabel self-esteem $53.3 \%$ lebih besar pada kategori tinggi. Sedangkan, pada variabel belonging lebih besar $51 \%$ pada kategori rendah. Pada variabel kolektivisme dan individualisme yang sama-sama didominasi oleh hasil sebaran respon pada kategori tinggi, $55.7 \%$ respon untuk variabel kolektivisme dan $66.2 \%$ respon untuk variabel individualisme. 


\section{Hasil Uji Hipotesis}

\section{Tabel 4}

Model Summary Analisis Regresi

\begin{tabular}{|c|c|c|c|c|}
\hline Model & $\mathbf{R}$ & R Square & Adjusted R Square & Std. Error of the Estimate \\
\hline$\overline{1}$ & $.431^{\mathrm{a}}$ & .186 & .132 & 7.893 \\
\hline
\end{tabular}

Berdasarkan tabel 4 terlihat bahwa nilai $R$-Square sebesar 0.186 atau 18.6\%. Artinya, seberapa besar bervariasinya pengungkapan marah di jejaring sosial (anger out) dipengaruhi oleh variabel independen dalam penelitian ini yaitu, jenis kelamin, kepribadian (neuroticism, extraversion, openness to experience, agreeableness, dan conscientiousness), dukungan sosial (tangible, appraisal, self-esteem, dan belonging), kolektivisme-individualisme serta anonimitas sebesar $18.6 \%$ sedangkan $81.4 \%$ lainnya dipengaruhi oleh variabel lain di luar penelitian ini.

\section{Tabel 5}

ANOVA pengaruh IV terhadap Pengungkapan Marah (Anger-out) di Jejaring sosial

\begin{tabular}{|c|c|c|c|c|c|c|}
\hline \multicolumn{2}{|c|}{ Model } & \multirow{2}{*}{$\begin{array}{l}\text { Sum of Squares } \\
2790.948\end{array}$} & \multirow{2}{*}{$\begin{array}{l}\mathbf{d f} \\
13\end{array}$} & \multirow{2}{*}{$\begin{array}{l}\text { Mean Square } \\
214.688\end{array}$} & \multirow{2}{*}{$\begin{array}{l}\mathbf{F} \\
3.446\end{array}$} & \multirow{2}{*}{$\begin{array}{l}\text { Sig. } \\
.000^{\mathrm{b}}\end{array}$} \\
\hline$\overline{1}$ & Regression & & & & & \\
\hline & Residual & 12211.955 & 196 & 62.306 & & \\
\hline & Total & 15002.904 & 209 & & & \\
\hline
\end{tabular}

a. Dependent Variable: Anger_Out

b. Predictors: (Constant), Anonimitas, Appraisal, Jenis kelamin, Neuroticism, Kolektivisme, Openness, Individualisme, Conscientiousness, Extraversion, Agreeableness, Self_esteem, Tangible, Belonging

Berdasarkan hasil uji F pada tabel 5 diperoleh bahwa nilai p (Sig) pada kolom paling kanan adalah $\mathrm{p}=0.000$ dengan nilai $\mathrm{p}<0.05$. Hal tersebut menunjukkan bahwa hipotesis nihil yang menyatakan bahwa "tidak ada pengaruh yang signifikan dari kepribadian (neuroticism, extraversion, openness to experience, agreeableness, dan conscientiousness), dukungan sosial (tangible, appraisal, selfesteem, dan belonging), kolektivisme-individualisme, anonimitas dan jenis kelamin terhadap pengungkapan marah di jejaring sosial", ditolak. Maka dapat disimpulkan bahwa ada pengaruh yang signifikan dari kepribadian (neuroticism, extraversion, openness to experience, agreeableness, dan conscientiousness), dukungan sosial (tangible, appraisal, self-esteem, dan belonging), kolektivisme-individualisme, anonimitas dan jenis kelamin terhadap pengungkapan marah di jejaring sosial. 
Tabel 6

Koefisien Regresi

\begin{tabular}{|c|c|c|c|c|c|c|}
\hline & \multirow[t]{2}{*}{ Model } & \multicolumn{2}{|c|}{ Unstandardized Coefficients } & \multirow{2}{*}{$\begin{array}{c}\text { Standardized } \\
\text { Coefficients } \\
\text { Beta }\end{array}$} & \multirow[t]{2}{*}{$\mathbf{t}$} & \multirow[t]{2}{*}{ Sig. } \\
\hline & & B & Std. Error & & & \\
\hline \multirow[t]{14}{*}{$\overline{1}$} & (Constant) & 23.992 & 9.176 & & 2.615 & .010 \\
\hline & Neuroticism & .174 & .071 & .189 & 2.447 & $.015^{*}$ \\
\hline & Extraversion & .088 & .079 & .094 & 1.124 & .262 \\
\hline & Openness & -.088 & .066 & -.091 & -1.333 & .184 \\
\hline & Agreeableness & .021 & .095 & .018 & .220 & .826 \\
\hline & Conscientiousness & -.087 & .073 & -.092 & -1.191 & .235 \\
\hline & Tangible & .192 & .088 & .192 & 2.183 & $.030 *$ \\
\hline & Appraisal & .058 & .086 & .060 & .670 & .504 \\
\hline & Self_esteem & -.048 & .086 & -.050 & -.556 & .579 \\
\hline & Belonging & -.134 & .105 & -.138 & -1.273 & .205 \\
\hline & Kolektivisme & .019 & .065 & .020 & .289 & .773 \\
\hline & Individualisme & .129 & .061 & .145 & 2.107 & $.036^{*}$ \\
\hline & Anonim/Tidak & .653 & 1.533 & .029 & .426 & .670 \\
\hline & Jenis kelamin & 7.898 & 1.760 & .297 & 4.488 & $.000 *$ \\
\hline
\end{tabular}

a. Dependent Variable: Anger_Out

b. Keterangan $(*)$ : Signifikan $(\mathrm{p}<0.05)$

Berdasarkan koefisien regresi pada tabel 6, maka dapat dijelaskan persamaan regresi sebagai berikut:

Pengungkapan marah di jejaring sosial $=23.992+0.174$ (neuroticism) +0.088 (extraversion) 0.088 (openness to experience) + 0.021 (agreeableness) - 0.087 (Conscientiousness) + 0.192 $($ tangible $)+0.058$ (appraisal) -0.048 (self-esteem $)-0.134$ (belonging) + 0.019 (kolektivisme) + 0.129 (individualisme) $+\mathbf{0 . 6 5 3}($ anonim) +7.898 (jenis kelamin) $+\mathrm{e}$

Dari persamaan regresi tersebut, dapat diketahui bahwa terdapat empat variabel yang nilai koefisien regresinya signifikan, yaitu: (1) neuroticism; (2) tangible; (3) individualisme; dan (4) jenis kelamin. Sedangkan sembilan variabel lainnya yaitu: extraversion, openness to experience, agreeableness,conscientiousness, appraisal, self-esteem,belonging, kolektivisme, dan anonimitas tidak menunjukkan nilai koefisien regresi yang signifikan. 


\section{Pengujian Proporsi Varians}

Tabel 7

Proporsi Varians Pengungkapan Marah di Jejaring Sosial Pada Setiap IV

\begin{tabular}{ccccccccccc}
\hline Model & $\mathbf{R}$ & $\boldsymbol{R}$ Square & $\begin{array}{c}\text { Adjusted } \boldsymbol{R} \\
\text { Square }\end{array}$ & $\begin{array}{c}\text { Std. Error of } \\
\text { the Estimate }\end{array}$ & $\begin{array}{c}\boldsymbol{R} \text { Square } \\
\text { Change }\end{array}$ & F Change & df1 & df2 & $\begin{array}{c}\text { Sig. F } \\
\text { Change }\end{array}$ \\
\hline 1 & $.201^{\mathrm{a}}$ & .040 & .036 & 8.320 & .040 & 8.746 & 1 & 208 & $.003^{*}$ \\
2 & $.206^{\mathrm{b}}$ & .042 & .033 & 8.331 & .002 & .447 & 1 & 207 & .505 \\
3 & $.209^{\mathrm{c}}$ & .044 & .030 & 8.345 & .001 & .293 & 1 & 206 & .589 \\
4 & $.215^{\mathrm{d}}$ & .046 & .027 & 8.355 & .002 & .500 & 1 & 205 & .480 \\
5 & $.224^{\mathrm{e}}$ & .050 & .027 & 8.358 & .004 & .886 & 1 & 204 & .348 \\
6 & $.249^{\mathrm{f}}$ & .062 & .034 & 8.326 & .012 & 2.549 & 1 & 203 & .112 \\
7 & $.249^{\mathrm{g}}$ & .062 & .030 & 8.346 & .000 & .050 & 1 & 202 & .823 \\
8 & $.265^{\mathrm{h}}$ & .070 & .033 & 8.330 & .008 & 1.777 & 1 & 201 & .184 \\
9 & $.281^{\mathrm{i}}$ & .079 & .038 & 8.311 & .009 & 1.879 & 1 & 200 & .172 \\
10 & $.282^{\mathrm{j}}$ & .080 & .033 & 8.330 & .000 & .091 & 1 & 199 & .763 \\
11 & $.320^{\mathrm{k}}$ & .102 & .052 & 8.247 & .023 & 5.028 & 1 & 198 & $.026 *$ \\
12 & $.320^{1}$ & .102 & .048 & 8.268 & .000 & .011 & 1 & 197 & .915 \\
13 & $431^{\mathrm{m}}$ & .186 & .132 & 7.893 & .084 & 20.141 & 1 & 196 & $.000^{*}$ \\
\hline
\end{tabular}

Predictors:neuroticism, extraversion, openness to experience, agreeableness, conscientiousness, tangible, appraisal, self-esteem, belonging, kolektivisme, individualism, anonimitas dan jenis kelamin.

Keterangan (*): signifikan

Berdasarkan data pada tabel 4.8 telah diketahui proporsi varian dari masing-masing variabel independen (IV) terhadap pengungkapan marah di jejaring sosial. Berikut penjelasannya:

a. Variabel neuroticism memberikan sumbangan sebesar $4 \%$ terhadap varian pengungkapan marah di jejaring sosial. Sumbangan tersebut signifikan dengan nilai sig $F$ change sebesar 0.003 (sig. < 0.05).

b. Variabel extraversion memberikan sumbangan sebesar $0.2 \%$ terhadap varian pengungkapan marah di jejaring sosial. Sumbangan tersebut tidak signifikan dengan nilai sig $F$ change sebesar 0.505 (sig. < 0.05).

c. Variabel openness to experience memberikan sumbangan sebesar $0.1 \%$ terhadap varian pengungkapan marah di jejaring sosial. Sumbangan tersebut tidak signifikan dengan nilai sig $F$ change sebesar 0.589 (sig. < 0.05 ).

d. Variabel agreeableness memberikan sumbangan sebesar $0.2 \%$ terhadap varian pengungkapan marah di jejaring sosial. Sumbangan tersebut tidak signifikan dengan nilai sig $F$ change sebesar 0.480 (sig. $<0.05$ ).

e. Variabel conscientiousness memberikan sumbangan sebesar $0.4 \%$ terhadap varian pengungkapan marah di jejaring sosial. Sumbangan tersebut tidak signifikan dengan nilai sig $F$ change sebesar 0.348 (sig. < 0.05 ).

f. Variabel tangible support memberikan sumbangan sebesar $1.2 \%$ terhadap varian pengungkapan marah di jejaring sosial. Sumbangan tersebut tidak signifikan dengan nilai sig $F$ change sebesar 0.112 (sig. <0.05). 
g. Variabel appraisal support memberikan sumbangan sebesar $0 \%$ terhadap varian pengungkapan marah di jejaring sosial. Sumbangan tersebut tidak signifikan dengan nilai sig $F$ change sebesar 0.823 (sig. $<0.05$ ).

h. Variabel self-esteem memberikan sumbangan sebesar $0.8 \%$ terhadap varian pengungkapan marah di jejaring sosial. Sumbangan tersebut tidak signifikan dengan nilai sig $F$ change sebesar 0.184 (sig. < 0.05 ).

i. Variabel belonging memberikan sumbangan sebesar $0.9 \%$ terhadap varian pengungkapan marah di jejaring sosial. Sumbangan tersebut tidak signifikan dengan nilai sig $F$ change sebesar 0.172 ( sig. < 0.05$)$.

j. Variabel kolektivis mememberikan sumbangan sebesar $0 \%$ terhadap varian pengungkapan marah di jejaring sosial. Sumbangan tersebut tidak signifikan dengan nilai sig $F$ change sebesar 0.763 (sig. < 0.05 ).

k. Variabel individualis mememberikan sumbangan sebesar $2.3 \%$ terhadap varian pengungkapan marah di jejaring sosial. Sumbangan tersebut signifikan dengan nilai sig $F$ change sebesar 0.026 (sig. <0.05).

1. Variabel anonimitas memberikan sumbangan sebesar $0 \%$ terhadap varian pengungkapan marah di jejaring sosial. Sumbangan tersebut tidak signifikan dengan nilai sig $F$ change sebesar 0.915 (sig. < 0.05).

m. Variabel jenis kelamin memberikan sumbangan sebesar $8.4 \%$ terhadap varian pengungkapan marah di jejaring sosial. Sumbangan tersebut signifikan dengan nilai sig $F$ change sebesar 0.000 (sig. <0.05).

Berdasarkan penjabaran di atas, maka dapat disimpulkan bahwa dari 13 variabel independen terdapat tiga variabel yang kontribusinya signifikan terhadap pengungkapan marah di jejaring sosial yaitu, variabel neuroticism, individualisme, dan jenis kelamin.

\section{Diskusi}

Berdasarkan hasil penelitian, diketahui bahwa 45.7\% atau setara dengan 96 dari 210 responden mengungkapkan marah pada kategori tinggi. Artinya, pada penelitian ini individu memiliki kecenderungan untuk mengungkapkan marah di jejaring sosial daripada secara tatap muka. Pada penelitian ini diketahui pula bahwa, perilaku pengungkapan marah yang paling sering dilakukan oleh responden di jejaring sosial yakni, dengan memposting perasaan marah menggunakan katakata kasar atau berupa sindiran.

Sedangkan berdasarkan data gambaran umum subjek penelitian, diketahui bahwa sebagian besar responden $(44.3 \%)$ mengungkapkan marah melalui laman jejaring sosial twitter. Menurut sebagian responden, twitter lebih nyaman digunakan sebagai tempat menyalurkan perasaan marah karena sebagian besar pengguna twitter mengakui bahwa pada aplikasi ini mayoritas orang-orang yang dikenal secara pribadi di luar jaringan, tidak mengikuti akun twitter mereka. Selain itu, diakui oleh responden bahwa pengguna twitter cenderung tidak peduli dan memaklumi ketika ada orang yang berkeluh kesah daripada di jejaring sosial yang lain.

Berbeda dengan alasan responden dalam menggunakan akun instagram untuk mengungkapkan marah, rata-rata responden mengatakan agar orang yang dituju mengetahui jika dirinya sedang marah, selain itu karna fitur instagram story hanya berdurasi 24 jam dan dalam fitur tersebut banyak fitur-fitur seperti memposting lagu, kata bijak atau sekedar gambar maka semakin mudah dan beragam cara bagi individu untuk mengungkapkan rasa marahnya di instagram, tidak selalu secara eksplisit mengungkapkan dalam kalimat marah. Sedangkan alasan mengunggah status marah di facebook karena pada akun tersebut tidak ada batas penulisan, dan di facebook terdapat fitur "hanya saya" yang dapat melihat unggahan yang dibuat sehingga hanya digunakan untuk 
meluapkan amarah seperti buku harian tanpa orang lain dapat melihatnya. Pada akun lainnya, responden menyebutkan whatsapp story, whisper dan blog. Pada akun tersebut rata-rata alasan mengapa individu menggunakannya karena akun-akun tersebut lebih bersifat pribadi dari pada akun jejaring sosial twitter, instagram, dan facebook. Jika disimpulkan, alasan individu mengungkapkan amarah di jejaring sosial karena individu merasa lebih lega setelah mengungkapkan rasa marah di jejaring sosial, tidak ada orang yang dapat dipercaya di dunia nyata untuk mendengarkan keluh kesahnya, serta sebagai cara untuk menyindir orang lain.

Sedangkan berdasarkan hasil uji pengaruh dalam penelitian ini, diketahui bahwa tipe kepribadian big five (neuroticism, extraversion, openness to experience, agreeableness, dan conscientiousness), dukungan sosial (tangible support, appraisal support, self-esteem dan belonging), kolektivismeindividualisme, anonimitas serta variabel demografi jenis kelamin terhadap pengungkapan marah di jejaring sosial menunjukkan bahwa terdapat pengaruh yang signifikan. Dari ketiga belas variabel yang diujikan pada penelitian ini, terdapat empat variabel yang berpengaruh secara signifikan terhadap pengungkapan marah di jejaring sosial. Keempat variabel tersebut yaitu neuroticism, tangible suppot, individualisme dan jenis kelamin.

Pada tipe kepribadian big five, neuroticism yang memiliki pengaruh secara signifikan dan berarah positif terhadap terjadinya pengungkapan marah di jejaring sosial. Artinya, semakin tinggi tingkat neuroticism seseorang, maka semakin tinggi pula perilaku seseorang dalam mengungkapkan marah di jejarinng sosial. Hal ini sesuai dengan hasil penelitian yang diungkapkan oleh Costa dan McCrae (1992) bahwa sifat marah sering dianggap sebagai aspek dari neuroticism. Sebab, ciri identik dari individu yang bersifat neuroticism adalah cenderung penuh dengan kecemasan dan emosional. Maka, ketika dihadapkan pada situasi yang tidak menyenangkan, tidak sesuai dengan harapan, individu cenderung akan meluapkan kemarahannya di jejaring sosial untuk melepaskan perasaan cemasnya. Hal ini sejalan dengan hasil penelitian yang dilakukan oleh Mill, et al. (2018), bahwa individu dengan kepribadian neurotic yang tinggi akan cenderung mengungkapkan kemarahannya secara terbuka (anger out) apalagi ketika perasaan marah muncul dalam kasus penghinaan. Pada jejaring sosial, setiap orang bisa dengan mudah mengutarakan apapun termasuk menghina orang lain, baik yang dikenal ataupun tidak. Sebab di dalam dunia daring mudah untuk menjangkau siapapun dan kondisi apapun, sehingga individu dengan sifat neurotic yang tinggi akan mudah untuk mengutarakan kemarahannya secara terbuka ketika dihadapkan dengan situasi tersebut.

Pada variabel kepribadian lain, yakni extraversion tidak berpengaruh secara signifikan dengan pengungkapan marah di jejaring sosial. Individu dengan kepribadian extraversion salah satunya ditandai dengan kesenangannya untuk berkumpul dan membangun hubungan dengan orang lain (McCrae \& Costa, 1999). Dalam penelitian ini rata-rata responden memiliki extraversion yang tinggi, sebenarnya dalam konteks ini individu dengan extraversion yang tinggi cenderung mengungkapkan marahnya secara terbuka, sebab dalam penelitian yang dilakukan oleh Pease \& Lewis (2015) dikatakan bahwa individu dengan extraversion yang rendah cenderung akan memendam amarahnya (anger-in). Maka jika dipadukan antara ciri dan hasil penelitian mengapa extraversion tidak berpengaruh secara signifikan dalam pengungkapan marah di jejaring sosial sebab, individu tidak ingin merusak hubungannya dengan orang lain. Sehingga, kemungkinan ia akan tetap mengungkapkan amarah secara terbuka, tetapi hanya kepada orang-orang tertentu saja. Tidak secara terbuka di jejaring sosial yang dilihat oleh banyak orang, karena hal tersebut dapat merusak hubungannya dengan orang banyak. 
Pada variabel lain yakni, openness to experiencediketahui pula bahwa tidak berpengaruh secara signifikan pada pengungkapan marah di jejaring sosial. Pada koefisien regresi juga menunjukkan arah yang negatif, berarti bahwa semakin tinggi tingkat openness seseorang maka semakin rendah kecenderungan seseorang untuk mengungkapkan marah di jejaring sosial. Maka, hal ini berarti tidak sesuai dengan kerangka berpikir yang mengatakan bahwa individu dengan kepribadian openness memiliki pemikiran terbuka yang mungkin berbeda dengan orang lain, menjadikan individu untuk menyuarakan ide-idenya termasuk ketidak-sesuaian persepsinya dengan persepsi orang lain sehingga membuatnya mudah mengungkapkan kemarahannya di jejaring sosial.

Individu dengan sifat openness to experience adalah seseorang yang terbuka dengan wawasan dan orisinalitas ide. Individu dengan sifat terbuka siap menerima berbagai stimulus yang ada dengan sudut pandang yang terbuka karena wawasan yang dimiliki tidak hanya luas tetapi juga mendalam. Berdasarkan ciri tersebut, peneliti dapat menyimpulkan bahwa tidak berpengaruhnya kepribadian openness to experience pada pengungkapan marah di jejaring sosial terjadi karena, ketika melihat ada sesuatu yang tidak sesuai dengan pola pikir individu atau mungkin terjadi perselisihan atau perdebatan yang mungkin memicu pertengkaran di jejaring sosial. Individu yang berkepribadian openness yang tinggi akan cenderung untuk mencoba mencari sisi positif dari setiap perdebatan yang terjadi, sehingga ketika mungkin ada perasaan marah yang muncul, individu akan cenderung untuk menyimpannya ke dalam dan melihat dari sisi yang lain. Sejalan dengan hasil penelitian yang dilakukan oleh Mill et al. (2018) bahwa ketika dihadapkan pada peristiwa yang mengejutkan individu dengan kepribadian openness yang tinggi akan cenderung untuk menahan sedikit amarahnya.

Pada variabel kepribadian agreeableness-pun sama bahwa ciri kepribadian ini tidak berpengaruh secara signifikan terhadap perilaku individu dalam mengungkapkan marahnya di jejaring sosial. Dikarenakan individu dengan kepribadian agreeableness memiliki ciri mudah percaya dan mudah menerima oleh orang lain maka ia tidak akan mengungkapkan perasaan marahnya di jejaring sosial. Dikarenakan selalu positif terhadap apapun yang terjadi, ketika dihadapkan pada situasi yang tidak menyenangkan, individu akan selalu mengambil hikmah dari setiap masalahnya. Sehingga ketika rasa amarah tersebut muncul, maka individu akan merefleksikannya ke dalam diri, tidak untuk diungkapkan ke jejaring sosial.

Terakhir pada faktor kepribadian conscientiousness tidak memiliki pengaruh yang signifikan terhadap pengungkapan marah di jejaring sosial. Berdasarkan definisi dari conscientiousness, bahwa individu dengan kepribadian ini memiliki kemampuan untuk menunda kepuasan. Dalam penjelasan dari hasil penelitian yang dilakukan oleh Martin (2013) bahwa individu melakukan pengungkapan marah di jejaring sosial dengan alasan untuk memuaskan perasaan mereka. Sehingga dapat diketahui bahwa individu dengan kepribadian conscientiousness cenderung untuk menekan perasaan marahnya karena ciri tersebut. Selain itu menurut definisi McCrae dan Costa (1999) bahwa individu dengan kepribadian conscientiousness memiliki ciri untuk mempertimbangkan konsekuensi dari perilaku seseorang sebelum bertindak. Sehingga hal ini pun dapat mengindikasikan bahwa, seseorang dengan conscientiousness yangtinggiakan berpikir panjang ketika ingin memposting sesuatu seperti menyindir orang lain atau mungkin ikut terlibat dalam pertengkaran sehingga dapat mengurangi konsekuensi yang mungkin muncul dikemudian hari.

Pada faktor selanjutnya, yang memengaruhi pengungkapan marah yaitu, faktor dukungan sosial. Dukungan sosial, terbagi atas empat dimensi yaitu tangible support, appraisal support, self-esteem, dan belonging. Dari keempat variabel tersebut, hanya tangible support yang memengaruhi pengungkapan marah. Hanya saja, terjadi perbedaan hasil penelitian dengan teori dukungan sosial pada umumnya yakni, segala jenis dukungan sosial memiliki pengaruh berbanding terbalik dengan pengungkapan marah. Tangible support pada penelitian ini berpengaruh positif pada pengungkapan marah, dapat diartikan bahwa semakin tinggi tangible support yang didapatkan oleh individu semakin tinggi pula kecenderungan seseorang untuk mengungkapkan marahnya di jejaring 
sosial.Manfaat dari besarnya dukungan tangible adalah individu merasa bahwa masih ada perhatian atau kepedulian dari lingkungan terhadap dirinya yang sedang mengalami masalah. Maka, ketika mengungkapkan amarahnya di jejaring sosial, ia merasa akan mendapat lebih banyak perhatian dan kepedulian dari lingkungan sekitarnya.

Pada ketiga dukungan sosial lainnya yakni appraisal support, self-esteem, dan belonging tidak memiliki pengaruh yang signifikan terhadap pengungkapan marah di jejaring sosial. Hal ini sejalan dengan penelitian yang dilakukan oleh Yu dan John-baptiste (2016) kemungkinan hal ini terjadi karena item-item dukungan sosial yang ditanyakan merupakan dukungan sosial yang terjadi secara luring sehingga hal tersebut kemungkinan tidak dapat sepenuhnya memprediksi ekspresi emosi di jejaring sosial. Selain itu hal yang mungkin terjadi pula karena individu cenderung mengutarakan perasaannya secara nyata, sehingga ketika di dunia daring dukungan sosial yang rendah tidak membuat individu mengungkapkannya di jejaring sosial.

Faktor lainnya yang digunakan dalam penelitian ini yaitu faktor budaya. Faktor budaya terdiri dari kolektivisme dan individualisme. Dimensi kolektivisme tidak memengaruhi secara signifikan pengungkapan marah di jejaring sosial. Hal ini terjadi karena konteks jejaring sosial begitu luas, individu tidak hanya terhubung dengan kelompoknya tetapi juga dengan khalayak ramai (out group). Bukan berarti budaya kolektivis tidak mengungkapkan perasaan amarahnya, hanya saja tidak di konteks jejaring sosial. Berdasarkan uraian penelitian Matsumoto et al. (2006) yakni individu dengan menganut budaya kolektivisme cenderung untuk mengekspresikan kemarahannya dengan menyembunyikan, sebagai alasan untuk mencegah kekacauan sosial. Menundukkan tujuan pribadi yang mendukung kelompok adalah fitur utama kolektivisme. Dengan demikian, budaya kolektivistik menumbuhkan tampilan emosional ke arah kelompok yang mempertahankan dan memfasilitasi kohesi kelompok, keharmonisan, atau kerja sama ke tingkat yang lebih besar. Karena kemarahan dapat mengancam hubungan di dalam kelompok, budaya kolektif dikaitkan dengan norma untuk ekspresi kemarahan yang relatif kurang.

Sedangkan pada dimensi individualisme secara positif memengaruhi pengungkapan marah di jejaring sosial artinya, bahwa semakin tinggi tingkat individualisme seseorang maka semakin tinggi pula kecenderungan seseorang untuk mengungkapkan marah di jejaring sosial. Hal ini terjadi sebagaimana definisi dari unsur individualisme yaitu terkait kebebasan dalam mengungkapkan keinginan dan kebutuhan dengan jelas (Gelfand \& Triandis, 1998). Sehingga ketika mengalami suatu keadaan yang tidak menyenangkan di dalam diri, individu akan cenderung untuk mengungkapkan kemarahannya secara terbuka di jejaring sosial. Tanpa memandang bagaimana kondisi pengikutnya di jejaring sosial. Selain itu, hal ini sejalan dengan penelitian yang dilakukan oleh Park et al. (2013) bahwa kemarahan secara umum lebih sering muncul pada budaya individualis, sebagai alasan untuk mempertahankan ambisi pribadi maka dirasa ada sesuatu yang tidak adil dan membuat marah maka cenderung akan langsung mengungkapkan perasaannya agar tetap mempertahankan ambisinya tersebut.

Selanjutnya pada faktor anonimitas, tidak berpengaruh secara signifikan terhadap pengungkapan marah di jejaring sosial. Hal ini tidak sejalan dengan hasil penelitian yang dilakukan oleh Christopherson (2007) bahwa anonimitas memengaruhi cara orang berkomunikasi secara daring karena seseorang dapat menyerang orang lain secara langsung dan tidak perlu memberi targetnya kesempatan untuk merespon. Namun, pada kenyataannya saat ini di jejaring sosial tidak hanya akun anonim yang melakukan pengungkapan marah di jejaring sosial tetapi juga kepada individu yang menggunakan akun dengan identitas pribadinya. Kemungkinan menurut peneliti kebebasan individu dalam pengungkapan marah di akun pribadi dikarenakan saat ini pada beberapa akun jejaring sosial, khususnya instagram dan facebook terdapat fitur teman dekat sehingga individu dapat memilih siapa saja orang yang ia percaya untuk mengetahui apa yang ia posting termasuk saat mengungkapkan kemarahannya. Sehingga individu merasa lebih nyaman karena dengan harapan teman dekatnya akan mengerti tanpa menghakiminya. 
Selanjutnya faktor terakhir yang memengaruhi pengungkapan marah di jejaring sosial dalam penelitian ini adalah vaktor demografi jenis kelamin. Jenis kelamin menjadi faktor yang paling memengaruhi dalam penelitian ini. Berdasarkan hasil penelitian diketahui arah koefisien regresi positif yang berarti bahwa rata-rata perilaku mengungkapkan marah di jejaring sosial laki-laki lebih besar daripada perempuan. Hal ini sejalan dengan penelitian yang dilakukan oleh Alonzo \& Aiken (2004) bahwa laki-laki lebih banyak terlibat dalam flaming (suatu perselisihan yang terjadi antara dua orang atau lebih, lalu menyebar luas sehingga melibatkan banyak orang kemudian menjadi suatu keributan yang besar. Dan atau sebuah tindakan yang mengejek atau pun menghina seseorang sehingga menimbulkan perdebatan atau perselisihan diantara yang bersangkutan).

Perbedaan peran jenis kelamin pada pengungkapan marah ini di jelaskan oleh Kopper dan rekannya (Kopper, 1991; Kopper \& Epperson, 1996; dalam Kring, 2000) secara khusus bahwa lakilaki dan perempuan yang mendukung sejumlah karakteristik kepribadian maskulin, cenderung mendapat skor lebih tinggi pada skala Anger-Out daripada laki-laki dan perempuan yang mendukung sejumlah karakteristik kepribadian feminin. Sebaliknya, laki-laki dan perempuan dengan karakteristik kepribadian yang lebih feminin memiliki skor lebih tinggi pada skala Anger-In, menunjukkan bahwa karakteristik peran seks feminin dikaitkan dengan menekan amarah dan karakteristik peran seks maskulin dikaitkan dengan amarah yang diekspresikan secara lahiriah.

\section{Saran}

Pada penelitian ini, peneliti menyadari bahwa terdapat beberapa keterbatasan dan kelemahan yang harus dipertimbangkan ketika mengevaluasi hasil penelitian ini. Pertama, pada penggunaan self-report pada metode penelitian perilaku pengungkapkan marah yang kemungkinan dipengaruhi oleh social desirability dan responden bergantung pada bagaimana orang menafsirkan pengalaman kemarahan, tingkat pandangan mereka ke dalam perilaku mereka, dan interpretasi keseluruhan dari istilah "kemarahan". Lalu, yang kedua hasil regresi yang menunjukkan bahwa hanya terdapat tiga dimensi penelitian dan satu variabel demografi yang signifikan dari tiga belas dimensi yang diuji. Hal ini mengindikasikan bahwa dalam penelitian ini, peneliti masih kurang menelisik lebih dalam hal-hal lain yang menjadi prediktor dari pengungkapan marah di jejaring sosial.Sehingga pada penelitian selanjutnya diharapkan untuk menggunakan variabel lain seperti pola ekspresi emosi di luar jaringan, atau norma kelompok dengan paparan perilaku agresif, sensation seeking, pemaafan, dan lain sebagainya. Ketiga, dianjurkan juga untuk menggunakan aspek anger-in dan anger-control untuk mengetahui perilaku pengungkapan marah. Keempat, dalam hal pengukuran budaya pada penelitian ini belum mengukur secara lebih terperinci pengaruhnya pada diri individu dalam mengungkapkan marah. Maka, pada penelitian selanjutnya diharapkan untuk membuat alat ukur yang benar-benar bisa mengetahui bagaimana setiap budaya yang dibawa oleh individu memengaruhi dirinya dalam mengungkapkan marah, atau memungkinkan dengan membandingkan dua budaya yang memiliki karakteristik berbeda.

Berdasarkan hasil penelitian ini mengenai variabel-variabel yang telah terbukti memengaruhi pengungkapan marah di jejaring sosial. Peneliti menyarankan beberapa intervensi untuk meminimalisir pengungkapan marah di jejaring sosial. Dimulai dengan belajar untuk memahami diri sendiri, lalu penting untuk belajar mengontrol diri mengenai cara bagaimana harus bersikap ketika dalam kondisi marah, tetap tenang dan mengatur pernapasan. Selanjutnya, identifikasikan apa saja konsekuensi dari mengungkapkan marah secara terbuka dihadapan banyak orang. Hindari melakukan sesuatu yang akan disesali kemudian, bijak dalam menggunakan jejaring sosial serta belajar berempati sehingga bisa memahami segala sesuatu berdasarkan dua sisi yang berlawanan. 


\section{Daftar Pustaka}

Alonzo, M., \& Aiken, M. (2004). Flaming in electronic communication. Decision Support System, 36, 205-213. https://doi.org/10.1016/S0167-9236(02)00190-2

APJII. (2018). Penetrasi \& Profil Perilaku Pengguna Internet Indonesia Survei 2018. Apjii. Retrieved from www.apjii.or.id

Bushman, B. J. (2002). Does venting anger feed or extinguish the flame? Catharsis, rumination, distraction, anger, and aggressive responding. Personality and Social Psychology, 28, 724731. https://doi.org/https://doi.org/10.1177/0146167202289002

Bushman, B. J., Baumeister, R. F., \& Phillips, C. M. (2001). Do people aggress to improve their mood? Catharsis beliefs, affect regulation opportunity, and aggressive responding. Journal of Personality and Social Psychology, 81(1), 17-32. https://doi.org/10.1037/0022-3514.81.1.17

Christopherson, K. M. (2007). The positive and negative implications of anonymity in Internet social interactions : "On the Internet, Nobody Knows You're a Dog." Computers in Human Behavior, 23, 3038-3056. https://doi.org/10.1016/j.chb.2006.09.001

Cohen, S., \& Hoberman, H. M. (1983). Positive life events as buffers of life change stress. Journal of Applied Social Psychology, 13(12), 99-125. https://doi.org/10.1007/978-3-319-91211-0_29

Fan, R., Zhao, J., Chen, Y., \& Xu, K. (2014). Anger is More Influential than Joy: Sentiment Correlation in Weibo. PLoS ONE, 9(10). https://doi.org/10.1371/journal.pone.0110184

Gelfand, M. J., \& Triandis, H. C. (1998). Converging Measurement of Horizontal and Vertical Individualism and Collectivism. Journal of Personality and Social Psychology, 74(1), 118128.

Iqbal, M., Rosramadhana, R., Amal, B. K., \& Rumapea, M. E. (2018). Penggunaan Google Forms Sebagai Media Pemberian Tugas Mata Kuliah Pengantar Ilmu Sosial. Jurnal Pendidikan Ilmu-Ilmu Sosial, 10(1), 120-127. https://doi.org/10.24114/jupiis.v10i1.9652

Kramer, A. D. I., Guillory, J. E., \& Hancock, J. T. (2014). Experimental evidence of massive-scale emotional contagion through social networks. Proceedings of the National Academy of Sciences, 111(24), 8788-8790. https://doi.org/10.1073/pnas.1320040111

Kring, A. M. (2000). Gender and anger . In A. H. Fisher (Ed.), Gender and Emotion: Social Psychological Perspectives (pp. 211-231). Cambridge: Cambridge University. https://doi.org/10.1017/CBO9780511628191.011

Lapidot-lefler, N., \& Barak, A. (2012). Effects of anonymity, invisibility , and lack of eye-contact on toxic online disinhibition. Computers in $\mathrm{Hu}$

Lee, C. S. (2012). Exploring emotional expressions on YouTube through the lens of media system dependency theory. New Media and Society, 14(3), 457-475. https://doi.org/10.1177/1461444811419829

Martin, R. C., \& Vieaux, L. E. (2016). 9 the digital rage: How anger is expressed online. In A. Przepiorka \& M. Coleshill (Eds.), The Psychology of Social Networking: Communication, Presence, Identity and Relationships in Online Communities (pp. 117-126). Berlin: De Gruyter.

Martin, R. C., Coyier, K. R., VanSistine, L. M., \& Schroeder, K. L. (2013). Anger on the Internet: The perceived value of rant-sites. Cyberpsychology, Behavior, and Social Networking, 16(2), 119-122. 
Matsumoto, D., Yoo, S. H., \& Chung, J. (2006). The Expression of Anger across Cultures. In M. Potegal, G. Stemmler, \& C. Spielberger (Eds.), International Handbook of Anger (pp. 1-17). New York: Springer, New York, NY. https://doi.org/https://doi.org/10.1007/978-0-38789676-2_8

McCrae, R. R., \& Costa, P. T. (1999). A five-factor theory of personality. In Handbook of personality: Theory and research (2nd ed) (2nd ed., pp. 139-153). New York: Guilford. https://doi.org/10.1111/j.1600-0706.2011.19910.x

Mill, A., Kööts-Ausmees, L., Allik, J., \& Realo, A. (2018). The role of co-occurring emotions and personality traits in anger expression. Journal Frontiers in Psychology, 9(123), 1-13. https://doi.org/10.3389/fpsyg.2018.00123

Park, J., Kitayama, S., Markus, H. R., Coe, C. L., Miyamoto, Y., Karasawa, M., ... Ryff, C. D. (2013). Social status and anger expression: The cultural moderation hypothesis. American Psychological Association, 13(6), 1122-1131. https://doi.org/10.1037/a0034273

Parlamis, J. D. (2012). Venting as emotion regulation: The influence of venting responses and respondent identity on anger and emotional tone. International Journal of Conflict Management, 23(1), 77-96. https://doi.org/10.1108/10444061211199322

Pease, C. R., \& Lewis, G. J. (2015). Personality links to anger: Evidence for trait interaction and differentiation across expression style. Personality and Individual Differences, 74, 159-164. https://doi.org/10.1016/j.paid.2014.10.018

Rösner, L., \& Krämer, N. C. (2016). Verbal venting in the social web : effects of anonymity and group norms on aggressive language use in online comments. Social Media + Society, 2(3). https://doi.org/10.1177/2056305116664220

Rustian, R. S. (2012). Apa itu Sosial Media. Retrieved September 3, 2019, from http://www.unpas.ac.id/apa-itu-sosial-media/

Spielberger, C. D., Reheiser, E. C., \& Sydeman, S. J. (1995). Measuring the Experience , Expression , and Control of Anger. Issues in Comprehensive Pediatric Nursing, 18:3, 207232. https://doi.org/10.3109/01460869509087271

Sucahyo, N. (2015). Menghina Melalui Media Sosial, Mahasiswi UGM Divonis 2 Bulan Penjara. Retrieved December 22, 2018, from https://www.voaindonesia.com/a/menghina-melaluimedia-sosial-mahasiswi-ugm-divonis-2-bulan-penjara/2701021.html

Tosepu, Y. A. (2018). Social Media dan \& Social Network (Perbedaan dan klasifikasinya). Retrieved September 3, 2019, from http://yusrintosepu.wixsite.com/yoes/singlepost/2018/04/23/Social-Media-dan-Social-Network-Media-Sosial-Jejaring-Sosial-Perbedaandan-klasifikasinya

Yu, H., \& John-baptiste, S. (2016). Emotion expression on social networking sites: A study of young persons' use of Facebook and Twitter in the UK. In Proceedings of the 5th Annual International Conference on Cognitive and Behavioural Psychology. https://doi.org/https://doi.org/10.5176/2251-1865_cbp16.20 